\title{
ENVIRONMENTAL IMPACTS OF SOME EGYPTIAN ELECTRIC ARC FURNACE SLAG UNDER DIFFERENT COOLING RATES
}

\author{
Ismail, A. I. M. ${ }^{(1)}$; Awad, S, A. ${ }^{(2)}$ and Mwafy, M. A. G. ${ }^{(3)}$ \\ 1) Geological Sciences Department, National Research, Centre 2) Geology \\ Department, Faculty of Science, Ain Shams University 3) Central Laboratory \\ Department, Egyptian Mineral Resources Authority
}

\begin{abstract}
Electric arc furnace (EAF) slag is a byproduct materials its chemical composition more closely to the cement clinker and composed mainly from different types of calcium silicate minerals. EAF slag utilization is limited due to the presence of polluting heavy metals $(\mathrm{Cr}, \mathrm{Ba}, \mathrm{V}$, etc.) that can be dangerous to the human health and the environment. This research studies the chemical, mineralogical, and the environmental impacts of some Egyptian EAF slag with different cooling rates.

The environmental impacts of the studied slag showed that all heavy metals except vanadium and chromium was found to be very low. From the leaching test the reuse or the uncontrolled dumping of the air cooled Egyptian EAF slag without a previous treatment can have negative effects on the environment in the long term. The cooling rate affects significantly the leaching of $\mathrm{Cr}$, without a significant relation of the original slag $\mathrm{Cr}$ content.

From the boiling test it was cleared that the percent of Free $\mathrm{CaO}$ and/or $\mathrm{MgO}$ in Egyptian EAF samples was negligible $(\sim 0)$ so that they have volume stability to be used as construction materials.

Keywords : Environmental impacts, Electric arc furnace slag, Leaching test
\end{abstract}

\section{INTRODUCTION}

Management of the natural resources and wastes are the most important goals which generate opportunities while decreasing the environmental disturbance. Preventing the depletion of natural resources and enhancing the 
usage of waste materials has become a challenge to the scientist and engineers (Reinhart, 1993). The huge quantities of waste and/or by-products were produced every year. With the increasing need to recycle these industrial by-products to protect the environment, there is a successful trial to utilize large quantities of such by-product in construction projects (Ismail and Belal, 2014).

Many waste products from several industries are occurring. The most one used in this study is slag waste materials. The names of slags are based on the furnaces from which they are generated. Slags classified into two types namely, blast-furnace slag and steel-furnace slag. Steel-furnace slag was classified into basic oxygen furnace (BOF) slag, electric arc furnace (EAF) slag and ladle slag.

The steel production in Egypt was increased in the last years to reach 6.7 million tons in 2013 that resulted in an alternative increase in the steel slag, at the same time the utilization scale of the steel slag in Egypt are very limited that make the remained steel slag follow an illegal disposal methods such as dumping in old mines or nearby lands. By such methods, steel slag might pollute the natural environment (Radwan, 2015).

About $90 \%$ of the whole weight of steel slag is made of Iron, calcium, aluminum, magnesium and siliceous oxides. From a mineralogical point of view steel slag is mainly made of Larnite, Wustite and Brownmillerite . Other compounds are anhydrous calcium silicates and silico-aluminates, gehlenite, bredigite, magnetite, magnesio-ferrite, and manganese oxides (Agostinacchio and Olita, 2005). 
EAF slag used in this study is a by-product generated after the melting and the primary acid refining of liquid steel. Its chemical composition is based on its content of calcium, iron and silicon oxides in a global amount of over $80 \%$ aluminum, magnesium, manganese and phosphorus oxides. EAF slag has a chemical composition close to that of the cement clinker compared to the ground granulated blast furnace slag (GGBFS) (Amin et al., 2015).

One of the most significant environmental impacts when handling the iron and steel slags is leaching of soluble components from the slag matrix, when these materials are in direct contact with soil or exposed to rainwater. Therefore, the knowledge about the chemical composition of leachates and their behavior is environmentally relevant (Miller and Donahue, 1998).

Radwan (2015) studied the metal leaching of the Egyptian EAF slag by a tank leaching test using distilled water and weak acid water in order to represent materials coming into contact with both fresh water and/or acid rains. The study showed that some metals like $\mathrm{Cd}, \mathrm{Pb}, \mathrm{Cu}, \mathrm{Ni}$ and $\mathrm{Mn}$ were not detected either in the case of distilled water or using weak acidic water. On the other hand another group of metals has a low or moderate detection like $\mathrm{Zn}, \mathrm{Cr}$ and Fe. Some metals like V , Ca , Mg , Al, and Si have a high detection frequency and hence the leaching test result showed that except $\mathrm{Cr}$, $\mathrm{V}, \mathrm{Al}$ metals and also the $\mathrm{pH}$ value of the EAF slag the levels of metals in EAF slag were lower than the limits of Egyptian law No. 48/1982 (Radwan (2015).

The type of the iron and steel slag cooling must be taken into consideration where rapid cooling of slag by water can result in an amorphous slag, encapsulating metals and oxides, and thereby lowering the 
solubility of the heavy metals compared to rock material used in road making (Tossavainen and Forssberg, 2000). The Water quenching of steel slag results in products with a high content of glassy material. If the cooling is rapid, the slag passes from a liquid state to a solid without development of a crystalline structure. Also the study concluded that by controlling cooling conditions, the mineral transformation and consequently the solubility of elements like chromium, vanadium and other heavy metals were occurring (Tossavainen et al., 2007).

\section{MATERIAL AND METHOD}

1. Materials Processing: Three samples of EAF slag were obtained from different steel making plants in Egypt S1, S2 and S3 (air cooled EAF slags). The water cooled slag (S4 and S5) were prepared by remelting and quenching of $\mathrm{S} 1$ and $\mathrm{S} 2$ in a water tank. Where the re-melting of the EAF was carried out in a magnesium oxide crucible system, the time for melting the slag was approximately eight hours after the electrical furnace temperature raise to $1600^{\circ} \mathrm{C}$. In this study as shown in [Fig. 1], where a Carbolite electrical furnace model RHF $17 / 25$ with maximum operating temperature $1700^{\circ} \mathrm{C}$ was used. The liquid slag was poured into a water tank containing water with a continuous water flow in and out to discard the hot water from the tank bottom. The generated slag granules were collected at the bottom of the water tank at the end of this process. The duration of the water cooling process and granulation was approximately a few seconds duration. 
2. Chemical composition: The overall chemical composition of the studied slags was analyzed by X-ray fluorescence (XRF) for major and trace elements using a Philips XRF instrument (Model PW 2404).

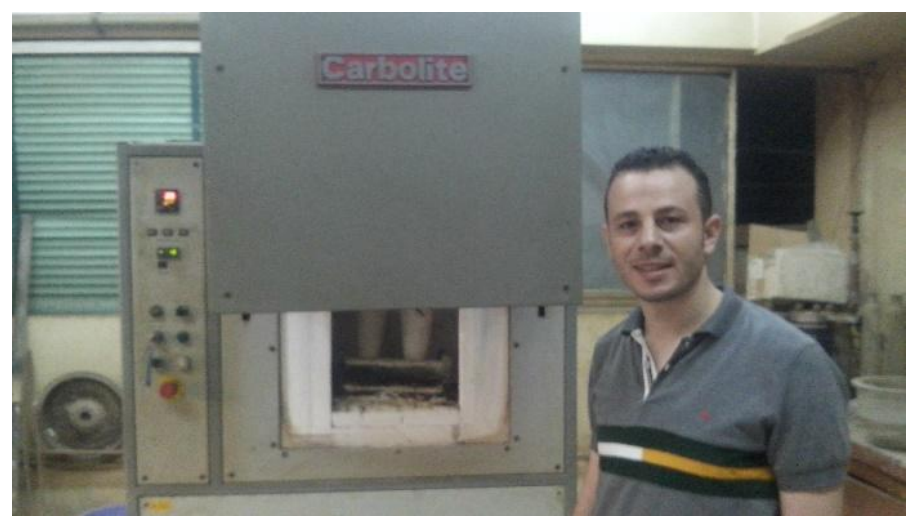

Fig. 1: The re-melting process using magnesium oxide crucible and Carbolite furnace.

3. The mineralogical composition: The crystalline phases were identified by X-ray powder diffraction (XRD), which carried out on a PANanalytical XRay diffraction equipment model X'Pert PRO with secondary monochromator, $\mathrm{Cu}$-radiation.

\section{The scanning electron microscopy}

SEM was carried out For S1 sample (air cooled EAF slag) and S4 sample (water cooled EAF slag) using SEM Model Quanta 250 FEG (Field Emission Gun) attached with EDX Unit (Energy Dispersive X-ray Analyses) with accelerating voltage $30 \mathrm{~K}$.V., magnification $14 \mathrm{x}$ up to 1000000 and resolutions for Gun.1n (FEI Company, Netherlands).

5. Alkalinity test (pH): $10 \mathrm{~g}$ is taken and diluted in $75 \mathrm{ml}$ distilled water by stirring. The $\mathrm{pH}$ value of the solution is noted with a $\mathrm{pH}$ meter after 1 hour, 2 hours and 24 hours and the average $\mathrm{pH}$ was calculated. 
6. Leaching Test: The method DIN 38414-S4 (Deutsche Norm, 1984) was the compliance test method used to evaluate the performance of the slags. In this test, $100 \mathrm{~g}$ of the dry mass of the residue (with a particle size $<10 \mathrm{~mm}$ ) is mixed in $1000 \mathrm{ml}$ of distilled water $(\mathrm{pH}=6.92)$, and submitted to an upside down agitation, in a rotary agitator, during $24 \mathrm{~h}$ at room temperature. The solid and liquid phases are separated by a filter of $0.45 \mu \mathrm{m}$ of pore size, and the liquid phase is then analyzed. The elemental analysis of leachates, in duplicate, was analyzed by ICP in a 720 ICP-OES, Agilent Technologies. The leachates of the five EAF slags S1, S2, S3, S4 and S5 were analyzed in order to monitor relevant parameters such as heavy metals (Al, Fe, V, and $\mathrm{Cr}$, As, $\mathrm{Pb}, \mathrm{Cd}, \mathrm{Cu}, \mathrm{Hg}, \mathrm{Ni}$ and $\mathrm{Zn}$ ).

7. Volume stability: In order to evaluate the expansive nature of slag the volume stability was carried out by performing Boiling test where for each EAF slag sample a twenty pieces with an average diameter $(50-150 \mathrm{~mm})$ and placed in a boiling water bath for 8 hours. After this time the loss in mass of the slag pieces was determined. By performing the Boiling test free $\mathrm{CaO}$ and/or $\mathrm{MgO}$ will react with water as a liquid, thus an expansion test has been carried out to reflect the slag volume stability (Radwan, 2015).

\section{RESULTS AND DISCUSSION}

The chemical composition of the five EAF slag samples presented in [Table 1]. The comparison between the five Egyptian EAF slag samples, Japanese slag and European slag showing that, significant concentrations of $\mathrm{Fe}_{\mathrm{x}} \mathrm{O}_{\mathrm{y}}, \mathrm{CaO}, \mathrm{SiO}_{2}, \mathrm{Al}_{2} \mathrm{O}_{3}, \mathrm{MgO}$ and $\mathrm{MnO}$ were detected in the Egyptian EAF slag under the study. The average of each group (Air and water cooled 
groups) was also represented in the [Table 1]. The representative Egyptian EAF slag main constituents are $\mathrm{CaO}, \mathrm{Fe}_{2} \mathrm{O}_{3}$, and $\mathrm{SiO}_{2}$ ranging from (33.5$38.3 \%),(29.8-41.33 \%)$ and (12.07-15.1\%) respectively. Water soluble chloride ion content was negligible in the studied samples $(<0.01 \%)$. Moreover, [Table 2] referring to the environmental impact, high concentrations of $\mathrm{Cr}, \mathrm{V}$ and $\mathrm{Sr}$ were observed; all the other elements investigated had negligible concentrations.

From the results of $\mathrm{IB} 2, \mathrm{M}_{\mathrm{b}}$ and $\mathrm{pH}$ that presented in [Table 3] it was clear that the EAF slag is an Alkaline by product with $\mathrm{pH}$ ranging from 11.1 to 11.8, and the samples S4 and S5 (water cooled EAF slag) have a Basicity indexes (IB2 and $\mathrm{M}_{\mathrm{b}}$ ) higher than those $\mathrm{S} 1, \mathrm{~S} 2$ and $\mathrm{S} 3$ (air cooled EAF slag). The results in the increased of the basicity index result in a more hydraulic slag (Amin et al., 2014).

From the XRD chart [Fig. 2] and [Table 4], the identified main minerals of the 3 air cooled EAF slag and the 2 water cooled are Larinite ( $\beta-\mathrm{Ca} 2 \mathrm{SiO} 4)$ and Wustite $(\mathrm{FeO})$. On the other hand Magnetite and Mayenite are characteristic in water cooled EAF slag [Fig. 2 ] and [Plate 1].

In [Fig. 2], the chart of S1 (air cooled EAF slag example) showing that the major minerals are Larnite and a Wustite-type solid solution. Also trace amounts of Wollastonite, Gehlenite, Monticellite, Srebrodolskite, and Brownmillerite are also observed. In [Plate 1] (A) showing small amounts of Cr. S4 chart (water cooled EAF slag example), the main phase is the Wustite and Wayenite phase. Also Larnite phase and Magnetite phase are constituted in minor amounts. From the SEM and EDXs results [Plate 1] (C), there are also many small grains of Cr-rich oxide. S5 chart (water cooled EAF slag 
example) showing that the Wustite and Mayenite are still abundant with minor amount of Larnite phase. From the XRD diffraction pattern the absence of Gehlenite was noted in the water cooled EAF slag.

Table 1: The chemical composition of the 5 EAF slag sample the major element $(\%)$

\begin{tabular}{|c|c|c|c|c|c|c|c|}
\hline \multirow{3}{*}{ Oxide } & \multicolumn{3}{|c|}{$\begin{array}{c}\text { Air cooled EAF slag } \\
\text { Samples }\end{array}$} & \multicolumn{2}{c|}{$\begin{array}{c}\text { Water cooled } \\
\text { EAF slag } \\
\text { mSamples }\end{array}$} & \multicolumn{2}{c|}{$\begin{array}{c}\text { European } \\
\text { EAF slag }\end{array}$} \\
\cline { 2 - 9 } & $\mathbf{S 1}$ & $\mathbf{S 2}$ & $\mathbf{S 3}$ & $\mathbf{S 4}$ & $\mathbf{S 5}$ & $\begin{array}{c}\text { Low } \\
\text { MgO }\end{array}$ & $\begin{array}{c}\text { High } \\
\text { MgO }\end{array}$ \\
\hline \hline $\mathrm{SiO}_{2}$ & 14.2 & 12.87 & 12.07 & 13.89 & 12.31 & $8-17$ & $25-35$ \\
\hline $\mathrm{Al}_{2} \mathrm{O}_{3}$ & 8.1 & 6.61 & 7.12 & 8.2 & 6.44 & $4-7$ & $4-7$ \\
\hline $\mathrm{CaO}$ & 38.3 & 36.9 & 33.5 & 38.41 & 36.63 & $30-40$ & $25-35$ \\
\hline $\mathrm{Na}_{2} \mathrm{O}$ & 0.01 & 0.03 & $<0.01$ & $<0.01$ & 0.01 & - & - \\
\hline $\mathrm{K}_{2} \mathrm{O}$ & 0.02 & $<0.01$ & $<0.01$ & 0.01 & $<0.01$ & - & - \\
\hline $\mathrm{MgO}$ & 4.2 & 2.52 & 2.36 & 4.1 & 2.42 & $4-8$ & $8-15$ \\
\hline $\mathrm{Fe}_{\mathrm{x}} \mathrm{O}_{\mathrm{y}}$ & 29.8 & 36.61 & 41.33 & 29.92 & 37.66 & $18-28$ & $20-29$ \\
\hline $\mathrm{MnO}$ & 2.8 & 2.67 & 1.2 & 2.77 & 2.81 & $<6$ & $<6$ \\
\hline $\mathrm{TiO}_{2}$ & 0.44 & 0.34 & 0.43 & 0.41 & 0.31 & - & - \\
\hline $\mathrm{P}_{2} \mathrm{O}_{5}$ & 0.31 & 0.21 & 0.23 & 0.33 & 0.18 & $<1.5$ & $<1.5$ \\
\hline $\mathrm{Cl}^{2}$ & $<0.01$ & $<0.01$ & $<0.01$ & $<0.01$ & $<0.01$ & - & - \\
\hline $\mathrm{SO}_{3}$ & 0.1 & 0.07 & 0.06 & 0.07 & 0.04 & - & - \\
\hline $\mathrm{LOI}^{2}$ & 0 & 0 & 0 & 0 & 0 & - & - \\
\hline
\end{tabular}

*: Radwan (2015) 
Table 2: The chemical composition of the five Egyptian EAF slag sample the trace element unit by (ppm).

\begin{tabular}{|c|c|c|c|c|c|}
\hline \multirow{2}{*}{ Element } & \multicolumn{3}{|c|}{ Air cooled EAF slag } & \multicolumn{2}{c|}{ Water cooled EAF slag Samples } \\
\cline { 2 - 6 } & $\mathbf{S 1}$ & S2 & S3 & S4 & S5 \\
\hline $\mathrm{V}$ & 690.7 & 436.4 & 184.2 & 640.4 & 420.7 \\
\hline $\mathrm{Cr}$ & 11687.6 & 5627.8 & 10947.0 & 10474.7 & 5421.3 \\
\hline $\mathrm{Ni}$ & 10.7 & 19.2 & 17.2 & 11.1 & 18.2 \\
\hline $\mathrm{Cu}$ & 260.5 & 191.1 & 210.3 & 250.9 & 187.4 \\
\hline $\mathrm{Zn}$ & 316.3 & 160.6 & 109.4 & 309.8 & 147.8 \\
\hline $\mathrm{Co}$ & 120.4 & 99.2 & 100.3 & 107.1 & 89.4 \\
\hline $\mathrm{Sr}$ & 1027.1 & 475.4 & 680.8 & 1007.8 & 472.2 \\
\hline $\mathrm{Y}$ & 7.4 & 6.1 & 7.1 & 6.5 & 5.6 \\
\hline $\mathrm{Zr}$ & 137.1 & 200.6 & 159.2 & 137.3 & 178.8 \\
\hline $\mathrm{Nb}$ & 76.5 & 56.8 & 61.1 & 77.0 & 49.7 \\
\hline $\mathrm{Ba}$ & 110.4 & 160.1 & 178.3 & 108.7 & 124.2 \\
\hline $\mathrm{La}$ & 31.5 & 32.8 & 28.6 & 27.0 & 28.7 \\
\hline $\mathrm{Pb}$ & 129.1 & 141.2 & 74.5 & 125.1 & 140.5 \\
\hline
\end{tabular}

Table 3: IB2, $\mathrm{Mb}$ and $\mathrm{pH}$ of the $5 \mathrm{EAF}$ slag samples with an average for air cooled group and water cooled group.

\begin{tabular}{|c|c|c|c|c|c|c|c|}
\hline \multirow{2}{*}{ Item } & \multicolumn{4}{|c|}{$\begin{array}{c}\text { Air cooled EAF slag } \\
\text { Samples }\end{array}$} & \multicolumn{3}{|c|}{$\begin{array}{c}\text { Water cooled EAF slag } \\
\text { Samples }\end{array}$} \\
\hline & S1 & S2 & S3 & Average & S4 & S5 & Average \\
\hline IB2* & 2.7 & 2.87 & 2.78 & 2.78 & 2.77 & 2.98 & 2.87 \\
\hline $\mathrm{M}_{\mathrm{b}}{ }^{*}$ & 1.91 & 2.02 & 1.87 & 1.93 & 1.93 & 2.08 & 2.00 \\
\hline $\mathrm{pH}$ & 11.2 & 11.4 & 11.1 & 11.23 & 11.5 & 11.8 & 11.65 \\
\hline
\end{tabular}

** $: \mathrm{Mb}=(\mathrm{CaO}+\mathrm{MgO}) /\left(\mathrm{SiO}_{2}+\mathrm{Al}_{2} \mathrm{O}_{3}\right)$ 


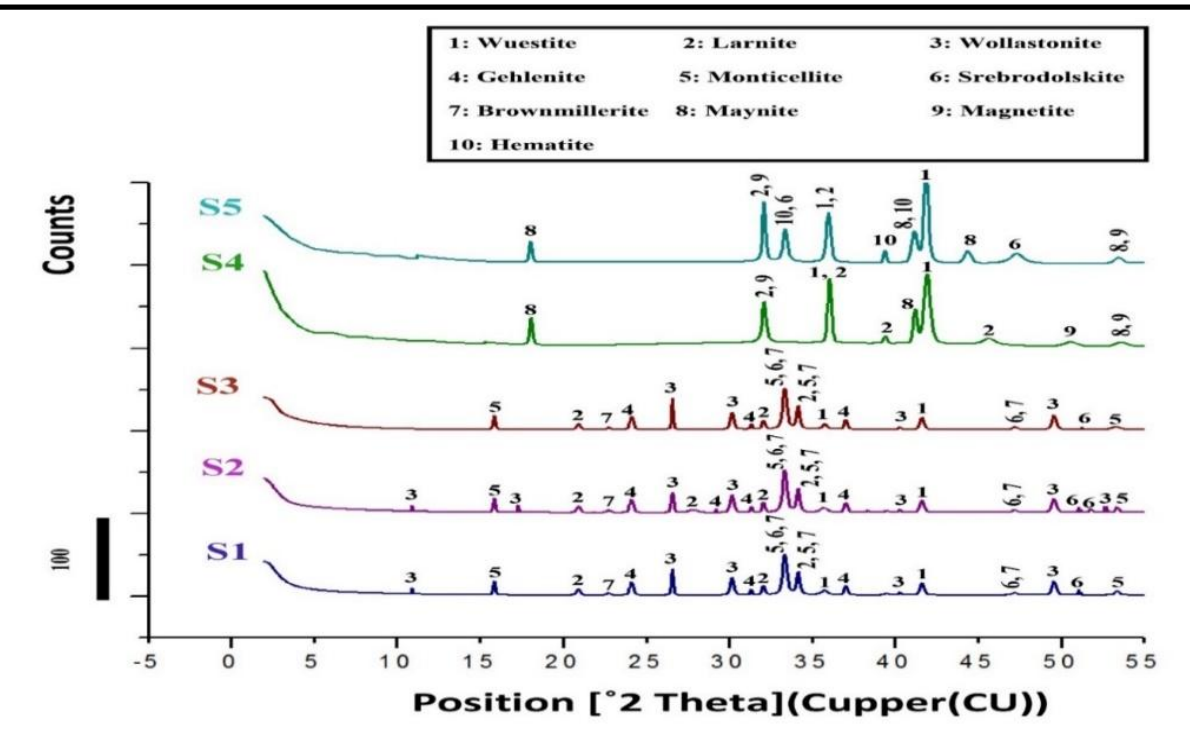

Fig. 2: XRD patterns of the investigated five Egyptian EAF slags at different cooling conditions.

Table 4: The mineral constituents of the five Egyptian EAF slag.

\begin{tabular}{|c|c|c|c|c|c|c|}
\hline Item & Formula & S1 & S2 & S3 & S4 & S5 \\
\hline \hline Wustite & $\mathrm{FeO}$ & Y & Y & Y & Y & Y \\
\hline Larnite & $\mathrm{Ca}_{2} \mathrm{SiO}_{4}$ & Y & Y & Y & Y & Y \\
\hline Wollatonite & $\mathrm{CaSiO}_{3}$ & Y & Y & Y & X & X \\
\hline Gehlenite & $\mathrm{Fe}_{2} \mathrm{SiO}_{4}$ & Y & Y & Y & X & X \\
\hline Monticellite & $\mathrm{CaMgSiO}_{4}$ & Y & Y & Y & X & X \\
\hline Srebrodolskite & $\mathrm{Ca}_{2} \mathrm{Fe}_{2}{ }_{2} \mathrm{O}_{5}$ & Y & Y & Y & X & Y \\
\hline Brownmillerite & $\mathrm{Ca}_{2}\left(\mathrm{Al}_{2}, \mathrm{Fe}_{2} \mathrm{O}_{5}\right.$ & Y & Y & Y & X & X \\
\hline Maynite & $\mathrm{Ca}_{12} \mathrm{Al}_{14} \mathrm{O}_{33}$ & X & X & X & Y & Y \\
\hline Magnetite & $\mathrm{Fe}_{3} \mathrm{O}_{4}$ & $X$ & $X$ & $X$ & $Y$ & $Y$ \\
\hline Hematite & $\mathrm{Fe}_{2} \mathrm{O}_{3}$ & $X$ & $X$ & $X$ & $X$ & $Y$ \\
\hline
\end{tabular}

$\mathrm{Y}$ : The mineral is present

$\mathrm{X}$ : The mineral is absent 
From S4 and S5 XRD charts [Fig. 2], the clear broadening of the peak width were a result of the rapid water cooling of the EAF slag, suggested that the clear broadening of the peak width may be caused due to a decreased in the crystallite size (Suryanarayana and Grant, 1998).

The volume stability in [Table 5] was carried out using boiling test for all the five Egyptian EAF slag samples. The results range from 0 to $0.03 \%$, proving that the percent of the free $\mathrm{CaO}$ and/or free $\mathrm{MgO}$ is very low or
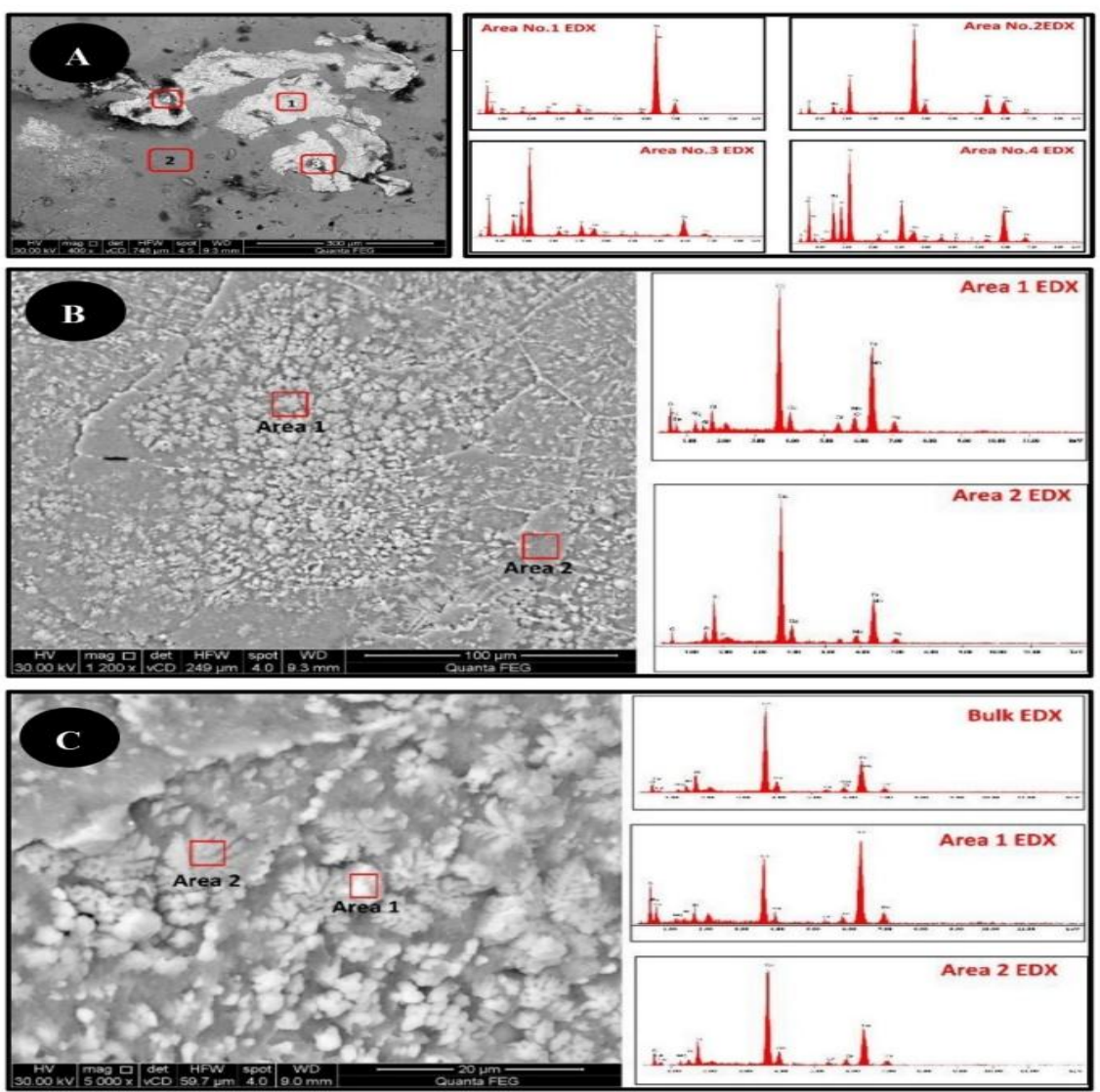

Plate 1: Micrographic appearance of slag samples where (A) represents the air cooled sample S1 and (B) and (C) represent the water cooled EAF slag sample.

Vol. 37, No.1, March. 2017 
approximately not founded that confirmed by XRD pattern [Fig. 2], where there was no presence of $\mathrm{CaO}$ and/or $\mathrm{MgO}$ peaks. Hence the Egyptian EAF slag under the study have a volume stability.

Table 5: Result of volume stability (boiling test)

\begin{tabular}{|c|c|c|c|c|c|}
\hline Item & S1 & S2 & S3 & S4 & S5 \\
\hline Mass Loss (\%) & $\mathbf{0 . 0 3}$ & $\mathbf{0 . 0 1}$ & $\mathbf{0 . 0 2}$ & $\mathbf{0}$ & $\mathbf{0}$ \\
\hline
\end{tabular}

The leaching characteristic of Egyptian EAF slag, in the present study was evaluated using DIN 38414-S4 method (Gomes and Pinto, 2006) using distilled water. Although the five Egyptian EAF slags (Air cooled and water cooled groups) show similar chemical compositions [Tables 2 and 3] and a similar basicity indexes IB2 or Mb with small differences as shown in [Table 3]. The obtained results of leaching tests are presented in [Table 6] was completely different.

Gomes and Pinto (2006) reported the information that, except for $\mathrm{Cr}$, the leaching of other elements is not relevant in terms of environmental impact.

In the present study the leaching test results [Table 6] showing that, except $\mathrm{Cr}, \mathrm{V}$ and $\mathrm{pH}$ of leachate, the leaching of other heavy metals are found to be very low. Vanadium metal has a high detective frequency. It is detected in the five EAF slag samples ranging from 0.007 to $0.03 \mathrm{ppm}$. The air cooled slag S1 release the greatest quantity of $\mathrm{Cr}$ (627 ppb), and when comparing these results with [Table 7] it was clear that the leachate $\mathrm{Cr}$ concentration was well above the limit of the Egyptian law No. 48/1982 and also the limit prepared by Italian regulation for the recovery of steel slags. The leaching of $\mathrm{Cr}$ is significantly smaller for water cooled EAF slag S4 (11 ppb) and 
practically zero (<5 ppb) for S5. The higher Cr leaching of S1 (627 ppb) could be explained due to its greater Cr content (11687.6 ppm). However the same hypothesis has no signification for $\mathrm{S} 4$, which represent a high content of $\mathrm{Cr}(10474.7 \mathrm{ppm})$ and the lowest $\mathrm{Cr}$ release $(<5 \mathrm{ppb})$. It seems to be clear that the cooling rate affects significantly the leaching of $\mathrm{Cr}$, modifying the phases in the slags and their solubility, without a significant relation of the original slag $\mathrm{Cr}$ content.

$\mathrm{pH}$ values using distilled water $(\mathrm{pH}=6.9)$ of leachate from the studied samples ranged from 11 to 11.7 Although the results of $\mathrm{pH}$ values are shown to be well above the limits of the Egyptian law no. 48/1982, and it was clear that the $\mathrm{pH}$ level is very near to be corrosive to aluminum or the galvanized steel pipes with direct contact to the slag. And so the uncontrolled dumping of the air cooled and/or the water cooled of the Egyptian EAF slag without a previous treatment can have negative effects on the environment in the long term due to its high leachate $\mathrm{pH}$. 
Table 6: Chemical composition results of $\mathrm{V}, \mathrm{Cr}, \mathrm{As}, \mathrm{Pb}, \mathrm{Cd}, \mathrm{Co}, \mathrm{Hg}, \mathrm{Ni}$ and $\mathrm{Zn}$ (ppm) and $\mathrm{pH}$ in the leachate resulted from leaching test according to DIN 38414-S4 for the five EAF slag samples

\begin{tabular}{|c|c|c|c|c|c|}
\hline \multirow{2}{*}{ 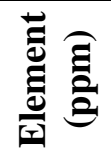 } & \multicolumn{3}{|c|}{ Air cooled EAF slag Samples } & \multicolumn{2}{|c|}{ Water cooled EAF slag Samples } \\
\hline & S1 & S2 & S3 & S4 & S5 \\
\hline$\overline{\mathrm{V}}$ & 0.01 & 0.03 & 0.01 & 0.009 & 0.007 \\
\hline $\mathrm{Cr}$ & 0.627 & 0.285 & 0.418 & 0.011 & $<0.005$ \\
\hline As & $<0.005$ & $<0.005$ & $<0.005$ & $<0.005$ & $<0.005$ \\
\hline $\mathbf{P b}$ & $<0.005$ & $<0.005$ & $<0.005$ & $<0.005$ & $<0.005$ \\
\hline Cd & $<0.005$ & $<0.005$ & $<0.005$ & $<0.005$ & $<0.005$ \\
\hline $\mathbf{C u}$ & 0.31 & 0.22 & 0.29 & 0.11 & 0.09 \\
\hline $\mathrm{Hg}$ & $<0.005$ & $<0.005$ & $<0.005$ & $<0.005$ & $<0.005$ \\
\hline $\mathrm{Ni}$ & 0.12 & 0.18 & 0.17 & 0.04 & 0.07 \\
\hline $\mathbf{Z n}$ & 0.27 & 0.19 & 0.18 & 0.2 & 0.11 \\
\hline pH & 11.2 & 11.5 & 11 & 11.4 & 11.7 \\
\hline
\end{tabular}

Table 7: Leaching limit values according to Council Decision 2003/33/EC (Gomes and Pinto, 2006) and the Egyptian law (No. 48/1982) limits (Radwan, 2015)

\begin{tabular}{|c|c|c|c|c|c|c|}
\hline \multirow{2}{*}{$\begin{array}{l}\text { Element } \\
\text { (ppm) }\end{array}$} & \multicolumn{3}{|c|}{ Leaching Limit Values } & \multicolumn{3}{|c|}{ Egyptian Law limit } \\
\hline & Inert & Non hazardous & Hazardous & Background & Fresh water & Non fresh water \\
\hline$\overline{\mathrm{V}}$ & - & - & - & - & - & - \\
\hline $\mathrm{Cr}$ & 0.5 & 10 & 70 & $<0.05$ & $<0.5$ & $<0.1$ \\
\hline As & 0.5 & 2 & 25 & $<0.01$ & $<0.1$ & $<0.1$ \\
\hline $\mathbf{P b}$ & 0.5 & $\mathbf{1 0}$ & $\mathbf{5 0}$ & $<0.01$ & $<0.1$ & $<0.1$ \\
\hline Cd & 0.04 & 1 & 5 & $<0.001$ & $<0.03$ & $<0.003$ \\
\hline $\mathrm{Cu}$ & 2 & 50 & 100 & $<0.001$ & $<1$ & $<0.5$ \\
\hline $\mathrm{Hg}$ & 0.01 & 0.2 & 2 & $<0.001$ & $<0.001$ & $<0.01$ \\
\hline $\mathbf{N i}$ & 0.4 & 10 & 40 & $<0.02$ & $<0.2$ & $<0.5$ \\
\hline $\mathbf{Z n}$ & 4 & 50 & 50 & $<0.01$ & $<1$ & 2 \\
\hline $\mathbf{p H}$ & - & - & - & 6.5-8.5 & $6-9$ & $6-9$ \\
\hline
\end{tabular}

-: Data not available 


\section{CONCLUSION}

- Egyptian EAF slag is a basic slag and its chemical composition is closer to the cement clinker.

- The XRD of Egyptian EAF slag reveals the presence of different kinds of calcium silicate in all samples.

- The mineralogical composition of the Egyptian EAF slag was complex for the studied EAF slag samples.

- From the boiling test results and XRD patterns the percent of free $\mathrm{CaO}$ and/or $\mathrm{MgO}$ were very low, therefor the Egyptian EAF slag under the study have a volume stability and hence it could be utilized as a construction material after studying its environmental impacts.

- The leaching test results have shown that all heavy metals except vanadium and chromium was found to be very low and insignificant in term of environmental impacts.

- Other factors rather than metal concentrations have to be considered when accessing the environmental impact of slags, such as cooling rate.

- From the leaching test the reuse or the uncontrolled dumping of the air cooled Egyptian EAF slag without a previous treatment can have negative effects on the environment in the long term. Thus, the pre-treatment of slag or its stabilization before reuse is recommended, even for low value applications.

- The cooling rate affects significantly the leaching of $\mathrm{Cr}$, modifying the phases in the slags and their solubility, without a significant relation of the original slag $\mathrm{Cr}$ content. 


\section{REFERENCES}

Agostinacchio M. and Olita S. (2005): Use of marginal materials in road constructions: Electric-arc-furnace slag, Proc. of 3rd Int. SIIV Congress, Bari (Italy), pp. 22-24.

Amin M.S., El-Gamal S.M.A., Abo-El-Enein S.A., El-Hosiny F.I., Ramadan M. (2015): Physico-chemical characteristics of blended cement pastes containing electric arc furnace slag with and without silica fume. HBRC Journal, 11, (3), 321-327.

Deutsche Norm, (1984): DIN 38414-S4, Deutsche Norm, Teil 4 Okt, 1984, pp. 464-475.

Gomes J. F.P. and Pinto C.G. (2006): Leaching of heavy metals from steelmaking slags. Revista de metalurgia, 42 (6) , 409-416.

Ismail A. I. M. and Belal Z. L. (2014): Influence of Slag on the improvement of engineering properties of different soils, Nile Delta, Egypt. Nature and Science; 12(3), 73-78.

Miller R. and Donahue R. (1995): Soils in our environment, 7th Edition, Prentice Hall, London, United Kingdom, , pp. 230-235.

Radwan G. M. (2015): Recovery, recycling and reuse of steel furnace slag under Egyptian condition.. Ph. D. Thesis, Institute of Environmental Studies and Research, Ain Shams University, Egypt, pp. 66, 74 and pp. 86-90.

Reinhart D. R. (1993): Waste Management Resources, (11), pp. 257-268.

Suryanarayana C. and Grant M. (1998): X-Ray Diffraction a Practical Approach, Plenum Press, New York, pp. 211-216. 
Tossavainen M. and Forssberg E. (2000): Studies of the leaching behaviour of rock material and slag used in road construction: a mineralogical interpretation. Steel Research 71 (11), 442-448.

Tossavainen M., Engstrom F., Yang Q., Menad N., Larsson M.L., Bjorkman B. (2007): Characteristics of steel slag under different cooling conditions. Waste Manage (Oxf) 27(7), 1335-1344.

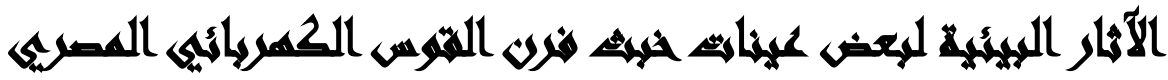

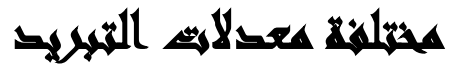

$[r]$

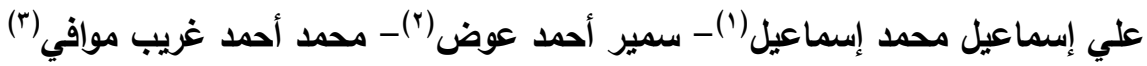

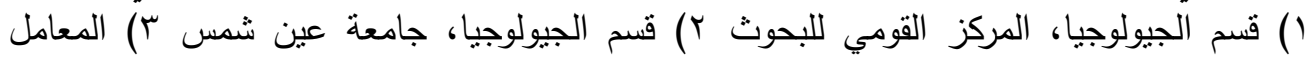
المركزية للهيئة المصرية العامة للثروة المعدنية

\section{المستخلس}

يعتبر خبث فرن القوس الكهربائي مخلف صناعي ينتشابة في تركيبة الكيميائي مخلفات الأسمنت

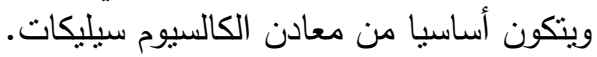

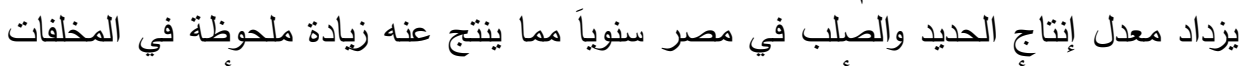

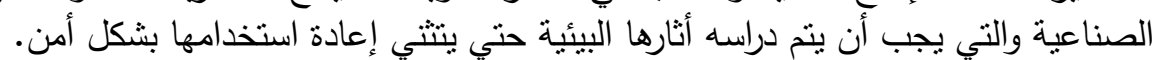
يتناول متن البحث دراسة جزئين رئيسيين:

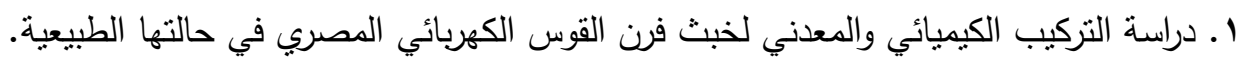

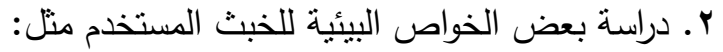
- درجة الحموضة بدضة

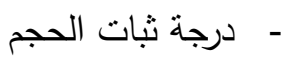

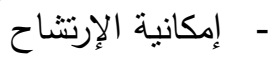
وفيما يلي بعض الاختبارات المعملية المختلفة التي تمت علي العينات الممثلة لأفران القوس الكهربائي المصرية: 


\section{خواص الخبث:}

أ- تحديد الخواص الكيميائية والمعدنية لعينات مختلفة من الخبث مقسمة لمجموعتين (مجموعة نم

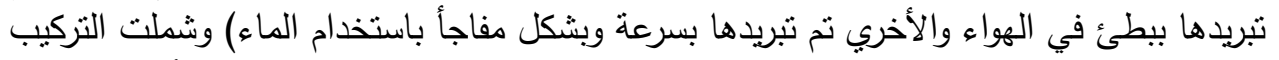

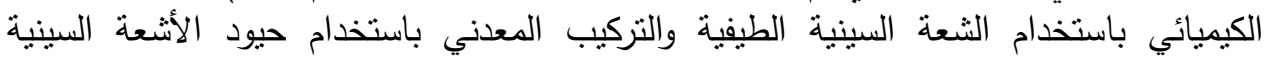
الحيودية والميكروسكوب الإلكتروني الماسعح.

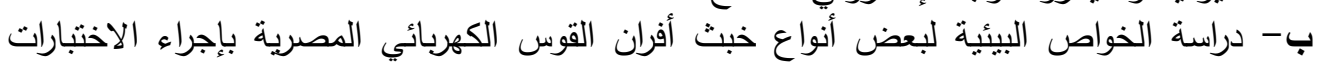

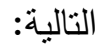

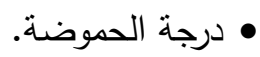

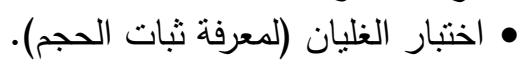

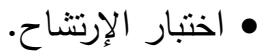

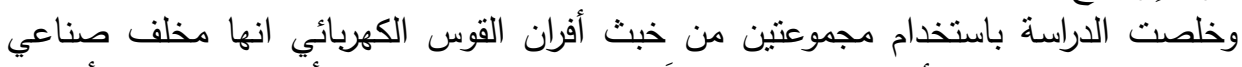

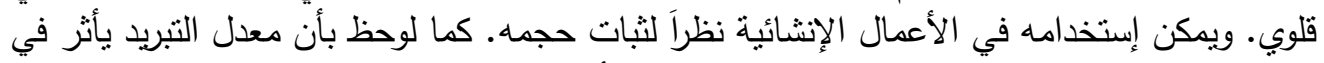

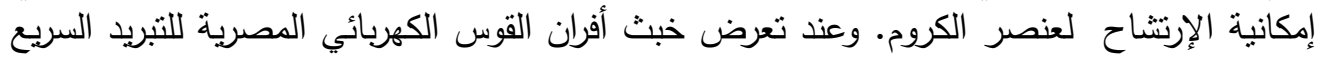

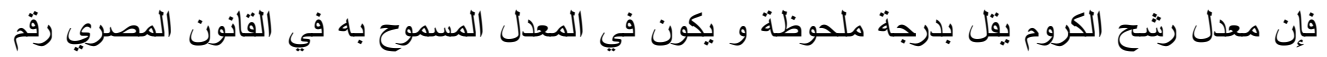

